\title{
シリアルディジタルビデオインタフェース用 チップセットの開発
}

正会員 中 村 和 彦 ${ }^{\dagger}$ 神 野 一 平 ${ }^{\dagger}$, 正会員 妹 尾 孝 憲 ${ }^{\dagger}$

\section{A Chip Set for Serial Digital Video Interface}

\author{
Kazuhiko Nakamura $^{\dagger}$, Ippei Kan-no ${ }^{\dagger}$ and Takanori Senoo ${ }^{\dagger}$
}

\begin{abstract}
We developed a chip set consisting of two analog ICs and two digital LSIs for serial transmission of digital video signals. It includes analog FIR filters as a part of an automatic cable equalizer that allows digital video signals to be transmitted through a coaxial cable. This chip set can transmit and receive composite NTSC/PAL, component 525/625, and wide component 525/625 digital video signals. It also includes multiplexing/demultiplexing functions for 24-bit audio and Error Detection and Handling (EDH) packets. With this chip set total digital broadcasting systems can easily be constructed.
\end{abstract}

\section{1. ま え がき}

近年，スタジオ用 $\mathrm{AV}$ 機器においては，VTR等に 見られるように急速にディジタル化が進行している. 画像品質・信頼性・保守性のさらなる向上のため, 機 器間の信号伝送, さらには放送局内のすべての伝送系 までも含めたかたちでのトータルディジタルシステム の構築が進みつつある。

このような背景を受けて, SMPTEにおいても， 10 ビットのパラレルディジタルビデオ信号をビット シリアルに変換してスクランブルド NRZI 符号とし て伝送する, シリアルディジタルビデオインタフェー スの規格化作業が急ピッチで行われている.ディジ夕 ルビデオ信号伝送に関してはすでに規格化作業が終了 (1)2), 音声信号・音声制御デー夕の多重化方式 ${ }^{3)} よ$ び, EDH（Error Detection and Handling）と呼ばれ
る伝送誤りの検出方式4)についても，ほぼ規格化作業 が終了しつつある。このシリアルディジタルビデオイ ンタフェースを使用すれば, コンポジットまたはコン ポーネントのディジタルビデオ信号と, 4 チャンネル の 24 ビットディジタル音声信号等の補助デー夕を, 1 本の同軸ケーブルで伝送することができる，従来の ビットパラレル方式でのディジタルビデオ信号のイン タフェースは, 伝送距離が $50 \mathrm{~m}$ と短い, コネクタが 大きい，音声等の多重化ができない（コンポジットの 場合）等の問題があり, 今後, シリアル方式のディジ タルビデオインタフェースに移行していくものと思わ れる。

今回, このシリアルディジタルビデオインタフェー スを低コストかつ小スペースにて実現するために，2 つのアナログバイポーラICと 2 つテディジタル CMOS ゲートアレイからなる, シリアルディジタル

キーワード：ディジタルビデオ信号, シリアル伝送, 波形等化, 多重化

1993 年 3 月 5 日受付, 1993 年 7 月 26 日最終受付

$\dagger$ 松下電器産業株式会社 映像音響研究センター映像研究所（广 540 大阪府大阪市中央区城見 2-1-61, TEL 06-947-0505)

†† Image Technology Research Laboratory, Audio and Video Research Center, Matsushita Electric Industrial Co., Ltd. (2-1-61,

Shiromi, Chuo-Ku, Osaka 540, Japan) 
ビデオインタフェース用チップセットを開発した。本 チップセットではアナログ FIR フィルタを使用した 波形等化回路を内蔵し, 同軸ケーブルの伝送損失を自 動補償する。また，24ビットディジタル音声信号等 の補助デー夕の多重化抢よび分離機能も内蔵した。

このチップセットの使用により，スタジオ用ディジ タル AV 機器へのシリアルディジタルビデオインタ フェースの組み込みが低コストにて可能となり，トー タルディジタルシステムの構築が容易になる.

\section{2. シリアルディジタルビデオインタフェース}

SMPTEにより規格化されたシリアルディジタル ビデオインタフェースのフォーマット概要を表 1 に示 す。コンポーネント信号に対しては，SMPTE 125 $\mathrm{M}^{5}$ )で規定されているパラレルディジタルビデオ信号 において，すでにEAV (End of Active Video), SAV（Start of Active Video）の同期信号が付加され ていることから，パラレル信号をそのままシリアルに 変換し, スクランブル後 NRZI 符号に変換して伝送 する。一方，コンポジット信号に対しては，パラレル 信号に同期信号が付加されていないことから，各ライ ンの水平ブランキング期間に TRS (Timing Reference Signal と呼ばれる“3 FFh”, “000 h”, “000 h”, “000 h”の 4 ワードとライン番号 ID からなる同期信 号を付加した後，シリアルに変換する。受信側におい ては，EAV，SAV，またはTRSからワード同期を 回復する，チャンネルコーディングの多項式は次式の とおりである。

$$
G(X)=\left(X^{9}+X^{4}+1\right)(X+1)
$$

表 1 シリアル伝送規格の概要

Specification of serial digital video interface.

\begin{tabular}{|c|c|c|c|c|}
\hline $\begin{array}{l}\text { ディジタル } \\
\text { ビデオ信号 }\end{array}$ & $\begin{array}{c}\text { コンポジット } \\
\text { NTSC }\end{array}$ & $\begin{array}{c}\text { コンポジット } \\
\mathrm{PAL}\end{array}$ & $\begin{array}{c}\text { コンポーネント } \\
525 / 625\end{array}$ & $\begin{array}{c}\text { ワイド* } \\
\text { コンポーネント } \\
525 / 625\end{array}$ \\
\hline $\begin{array}{c}\text { 伝送レート } \\
(\mathrm{Mb} / \mathrm{s})\end{array}$ & 143.18 & 177.34 & 270.0 & 360.0 \\
\hline $\begin{array}{l}\text { チャンネル } \\
\text { コーディング }\end{array}$ & \multicolumn{4}{|c|}{$\begin{array}{c}\text { スクランブルド NRZI } \\
G=\left(X^{9}+X^{4}+1\right)(X+1)\end{array}$} \\
\hline 同期ワード & \multicolumn{2}{|c|}{$3 \mathrm{FF}, 000,000,000$} & \multicolumn{2}{|c|}{$3 \mathrm{FF}, 000,000$} \\
\hline $\begin{array}{c}\text { 補助データ } \\
\text { ヘッダ }\end{array}$ & \multicolumn{2}{|c|}{$3 \mathrm{FC}$} & \multicolumn{2}{|c|}{$000,3 \mathrm{FF}, 3 \mathrm{FF}$} \\
\hline 信号振幅 & \multicolumn{4}{|c|}{$800 \mathrm{mV} \pm 10 \%$ （送信側， $75 \Omega$ 終端時） } \\
\hline DCオフセット & \multicolumn{4}{|c|}{$0.0 \mathrm{~V} \pm 0.5 \mathrm{~V}$ (信号中央值) } \\
\hline ジッタ & \multicolumn{4}{|c|}{ $\pm 0.25 \mathrm{~ns}$ 以下（立ち上がりエッジ） } \\
\hline
\end{tabular}

伝送路はアナログビデオ信号の伝送に用いられてい る $75 \Omega$ 同軸ケーブルの使用を前提としており， $75 \Omega$ 終端にて $800 \mathrm{mVpp} \pm 10 \%$ の振幅を規定している.

\section{3. チップセットの詳細}

今回開発したシリアルディジタルビデオインタフェ 一ス用チップセットのブロック図を図 1 に，また，仕 様を表 2 に示す．本チップセットはパラレル/シリア ル変換と同軸ケーブル駆動を行うドライバ IC, 伝送 後の信号の波形等化とシリアル/パラレル変換を行う レシーバICの 2 つのアナログバイポーラ IC と, 送 信側にて音声信号等の多重化を行うエンコーダ LSI, 受信側にて音声信号等の分離を行うデコーダLSI の 2 つのディジタル CMOS ゲートアレイからなり，コ

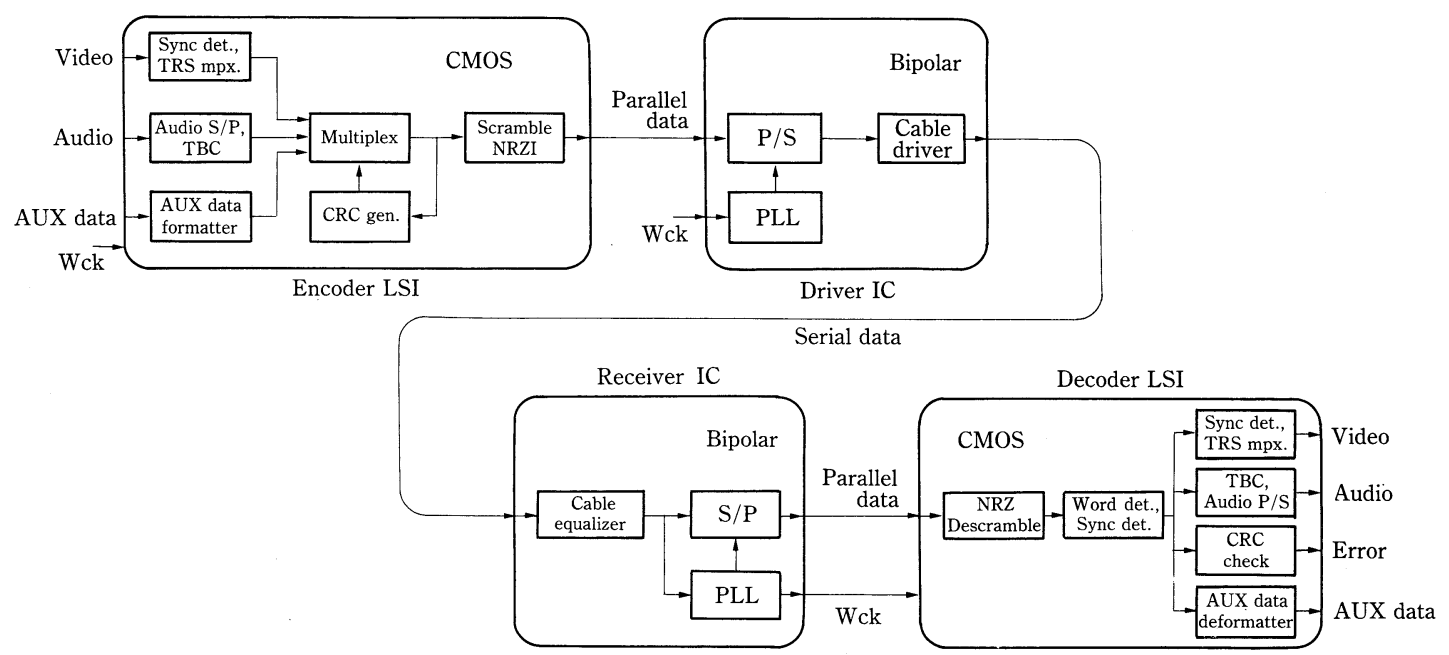

図 1 チップセットのブロック図

Block diagram of chip set. 
表 2 チップセット仕様

Specifications of chip set.

\begin{tabular}{c|c|c|c|c}
\hline & エンコーダ LSI & デコーダ LSI & ドライバ IC & レシーバ IC \\
\hline 機能 & 音声等多重化 & 音声等分離 & $\mathrm{P} / \mathrm{S}$, ケーブル駆動 & $\mathrm{EQ}, \mathrm{S} / \mathrm{P}$ \\
\hline プロセス & $0.8 \mu \mathrm{m} \mathrm{CMOS}$ & $0.8 \mu \mathrm{m} \mathrm{CMOS}$ & $1.0 \mu \mathrm{m}$ バイポーラ & $1.0 \mu \mathrm{m}$ バイポーラ \\
\hline 素子数 & 約 39000 ゲート & 約 40000 ゲート & 約 4100 素子 & 約 4600 素子 \\
\hline 消費電力 & 約 $700 \mathrm{~mW}$ & 約 $800 \mathrm{~mW}$ & 約 $550 \mathrm{~mW}$ & 約 $750 \mathrm{~mW}$ \\
\hline パッケージ & $160 \mathrm{pin} \mathrm{PQFP}$ & $160 \mathrm{pin} \mathrm{PQFP}$ & $68 \mathrm{pin} \mathrm{CQFP}$ & $68 \mathrm{pin} \mathrm{CQFP}$ \\
\hline
\end{tabular}

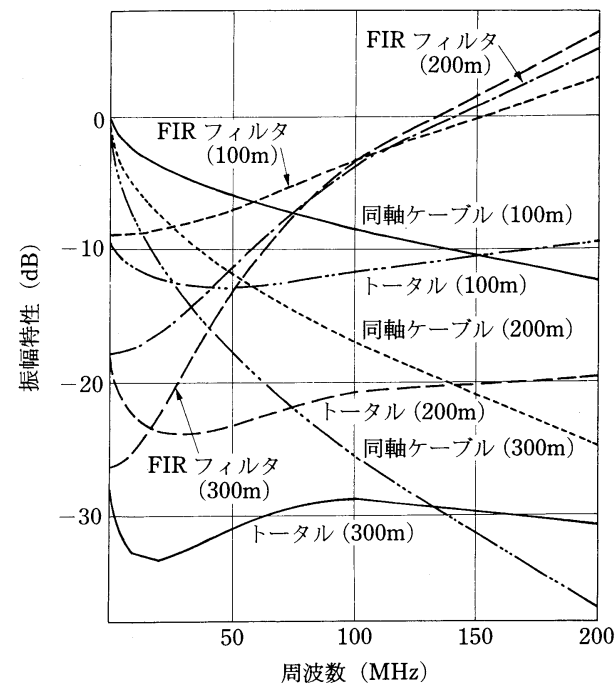

図 $25 \mathrm{C} 2 \mathrm{~V}$ 同軸ケーブル，波形等化回路およびト ータルでの振幅特性

Amplitude characteristics of coaxial cable, equalizer, and total.

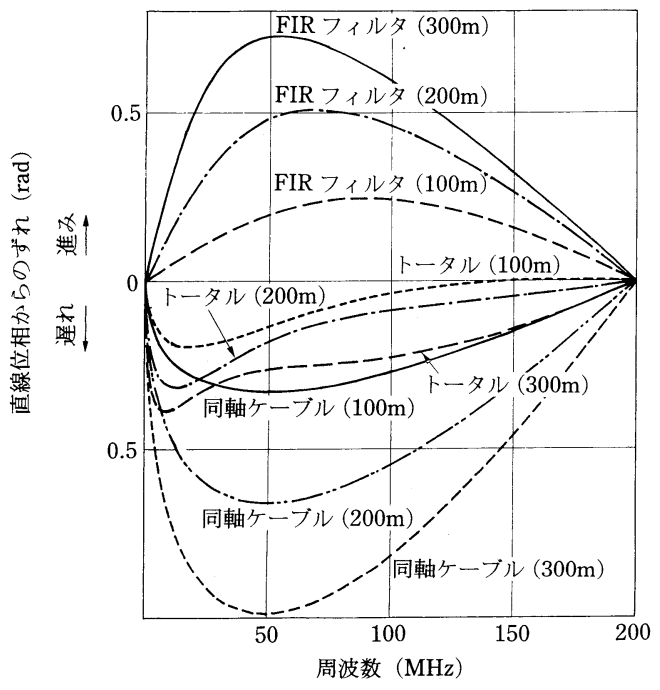

図 $35 \mathrm{C} 2 \mathrm{~V}$ 同軸ケーブル，波形等化回路およびト 一タルでの位相特性

Phase characteristics of coaxial cable, equalizer, and total.
ンポジット NTSC/PAL, コンポーネント 525/625, $18 \mathrm{MHz}$ サンプリングのワイドコンポーネント $525 /$ 625 の 6 種類のビデオ信号に対応している.このた め, ドライバ, レシーバ両 IC は $143 \sim 360 \mathrm{Mb} / \mathrm{s}$ の広 帯域の信号に対応する必要があり, 内部回路の差動化 を行っている。また，PALについては，VCO 自体の 発振周波数の変化幅が大きくならないよう, コンポー ネント/ワイドコンポーネント時にはVCO の原発振 そのものを用い, コンポジットNTSC/PAL 時には $\mathrm{VCO}$ の原発振を $1 / 2$ に分周して用いている.

\subsection{FIR フィルタによる波形等化}

同軸ケーブルによるシリアル伝送を行うにあたって は，同軸ケーブルによる伝送損失を補償する必要があ る、無ひずみでの伝送を行うための条件は，信号帯域 内での振幅周波数特性が一定で, かつ位相周波数特性 が周波数に比例すること(群遅延一定)である. 本チッ
プセットでは，このための受信側における波形等化を アナログ FIR フィルタを用いて実現した。

同軸ケーブルの減衰定数 $\alpha$ およ゙位相定数 $\beta$ は一 般に次式にて与えられる6).

$$
\begin{aligned}
& \alpha=K_{1} f^{1 / 2}+K_{2} f \\
& \beta=f\left(K_{3}+K_{4} f^{-1 / 2}\right)^{1 / 2}
\end{aligned}
$$

ただし, $f$ : 周波数

$K_{1}, K_{2}, K_{3}, K_{4}:$ 定数

図 2 に，上式から計算したケーブル長 $100 \mathrm{~m}, 200$ $\mathrm{m}, 300 \mathrm{~m}$ の $5 \mathrm{C} 2 \mathrm{~V}$ 同軸ケーブルの振幅周波数特性 を示した。同図にはFIRフィルタおよび, トータル での振幅周波数特性の計算值をあわせて示した。上記 計算に扔いては, FIRフィルタの遅延器の遅延時間 を一定として, 同軸ケーブルのケーブル長に対して 各々タップ係数のみ最適値に設定している．同様に図 3 は， $5 \mathrm{C} 2 \mathrm{~V}$ 同軸ケーブル，FIRフィルタおよびト 


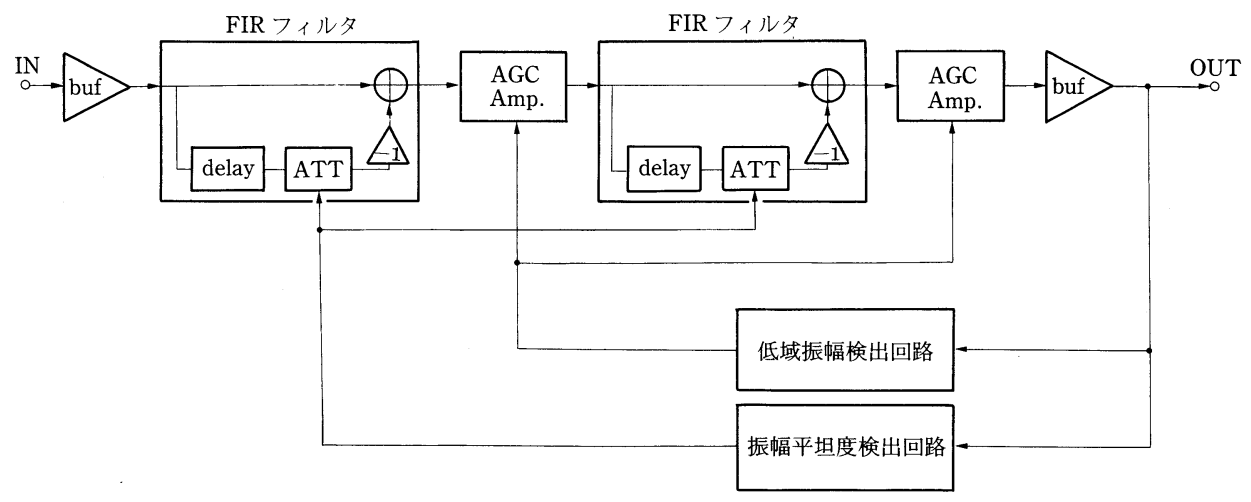

図 4 アナログFIR フィルタを用いた波形等化回路のブロック図

Block diagram of equalizer with analog FIR filter.

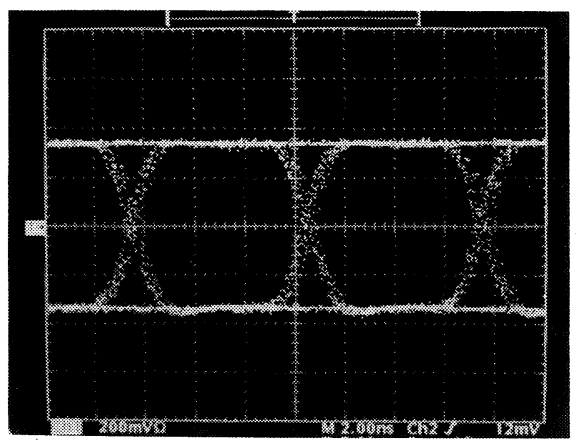

(a) 送信波形

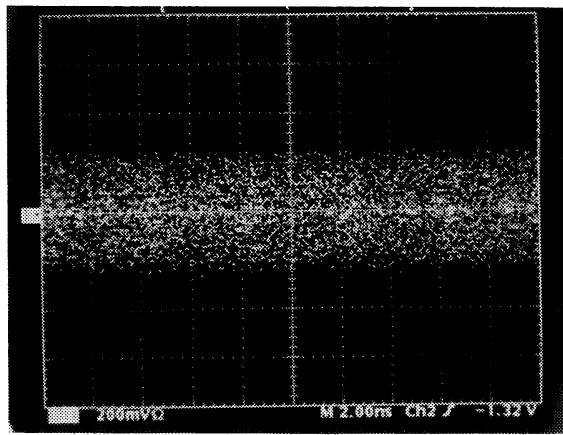

(c) 等化後のアイパターン

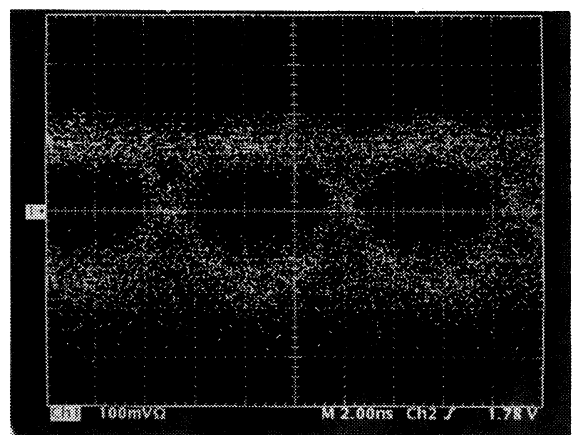

(b) $5 \mathrm{C} 2 \mathrm{~V}$ 同軸ケーブル $300 \mathrm{~m}$ 伝送後の波形

写真 1 アイパターン (コンポジットNTSC 信号) Eye patterns. (Composite NTSC)

(a) Original waveform, (b) Waveform transmitted through $300 \mathrm{~m}$ coaxial cable, (c) Eye pattern after equalization.

$\mathrm{m}$ までの同軸ケーブルの伝送損失を補償しようとす ると, フィル夕特性の制御感度が高くなりすぎるため に制御が難しくなる，そこで，FIRフィルタ 2 段の 構成とした。

振幅平担度検出回路にて波形等化回路出力信号の振 幅周波数特性のアンバランスが検出され，これに応じ て 2 段の FIR フィルタのタップ係数が同時に制御さ れることにより，ケーブル長に応じて自動的に波形等 化が行われる。この際, 全体としての信号振幅は低下 


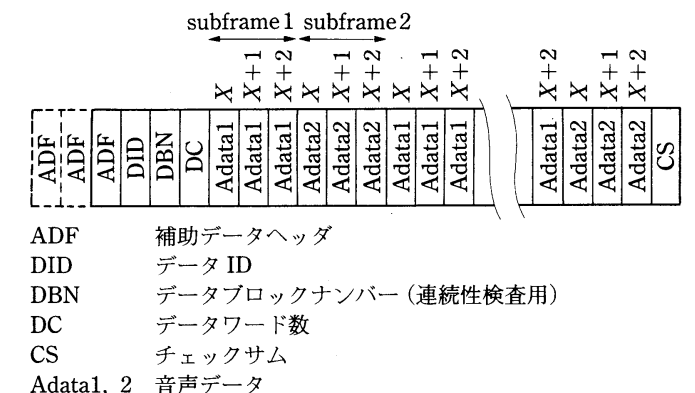

Adata1, 2 音声データ

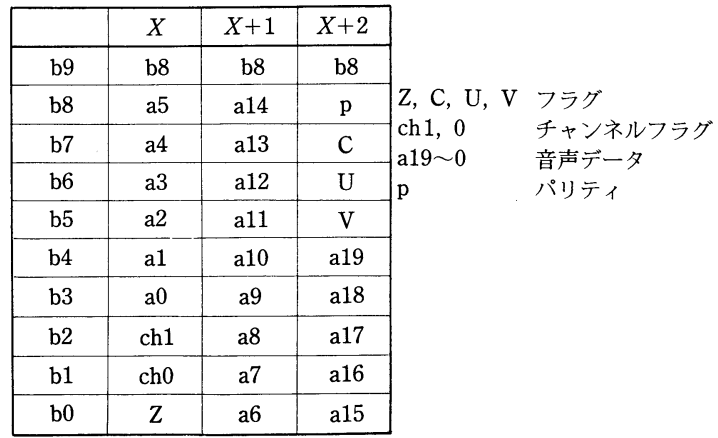

図 5 音声パケット構成

Audio packet structure.

するので，オートゲインコントロール (AGC) 広帯域 増幅器により所定の振幅となるようケーブル長に応じ て自動的に調整される。波形等化回路内に 2 重の制御 ループが存在することになるが，振幅特性を平担にす る等化特性制御ループの応答速度を広帯域 AGCルー プの応答速度より高速に設定することで, ハンチング 等の不安定動作を回避している.

実際に本 FIR フィルタ回路によりコンポジット NTSC ディジタルビデオ信号の $5 \mathrm{C} 2 \mathrm{~V}$ 同軸ケーブル による伝送を行った場合の, アイパターンを写真 1 に 示す。伝送レートは $143 \mathrm{Mb} / \mathrm{s}$ である。送信信号波形 を(a)に, $5 \mathrm{C} 2 \mathrm{~V}$ 同軸ケーブル $300 \mathrm{~m}$ 伝送後の信号 を(b)に, 自動波形等化回路による等化後のアイパ夕 ーンを(c)に示した。自動波形等化回路によって充分 な開口率が得られており, アナログ FIR フィルタに よる自動波形等化の有効性が確認できた。

\section{2 音声の多重化}

シリアルディジタルビデオインタフェースでは， 4 チャンネルのディジタル音声信号をビデオ信号に多重 化して伝送可能である. AES/EBUオーディオイン タフェースで伝送可能な 24 ビットの音声データおよ びフラグを, 図 5 に示すような 20 ビット音声データ と $\mathrm{C}, \mathrm{U}, \mathrm{V}, \mathrm{Z}$ の各フラグからなるパケット(音声パ ケット）と，図６に示すようなオキジャリに相当する

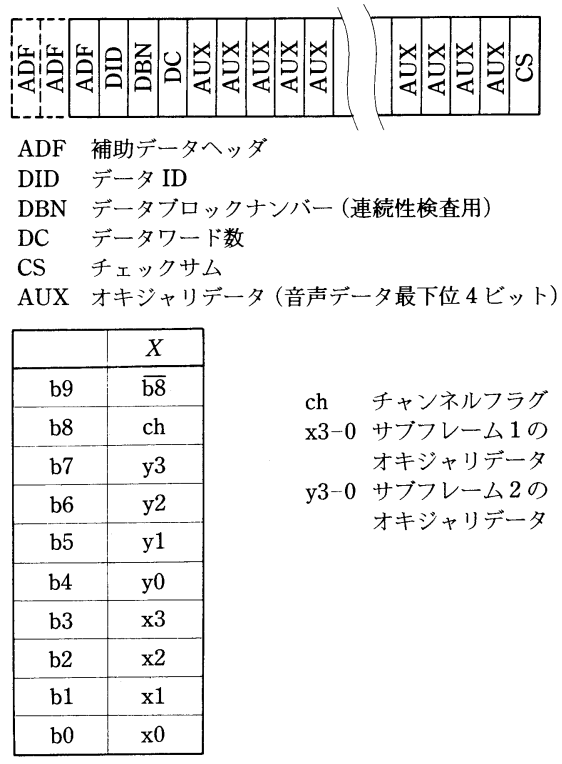

図 6 音声オキジャリパケット構成 Audio auxiliary packet structure.

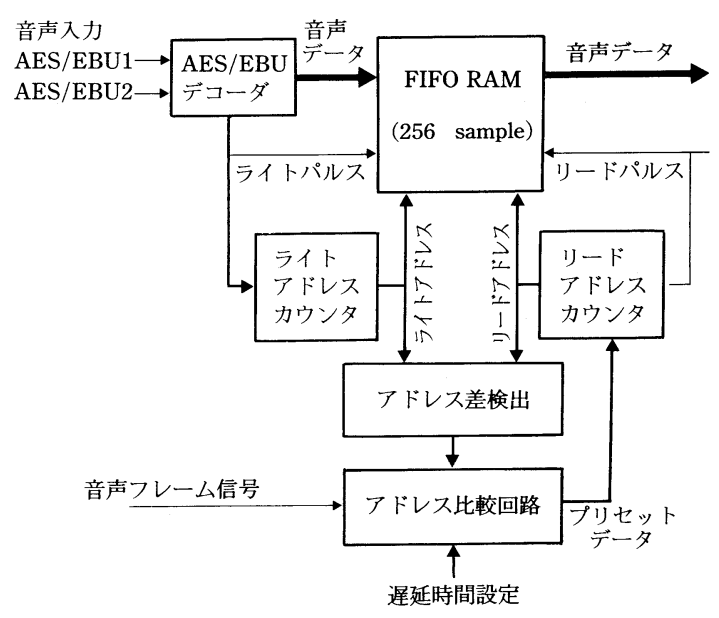

図 7 音声多重化回路のブロック図

Block diagram of audio multiplexer.

4 ビットの音声データからなるパケット（拡張パケッ ト）との 2 つのパケットに分けて, ディジタルビデオ 信号の水平ブランキング期間に多重化する.

本チップセットでは，このための音声多重化回路を チップ内にすべて内蔵した。本チップセットの音声多 重化回路のブロック図を図 7 に示す. 音声信号はビデ オ信号の水平ブランキング期間のみに多重化できるた め, 時間軸調整が必要となる. 特に 24 ビットの音声 信号データを多重化する場合, コンポジットディジタ ルビデオ信号の水平ブランキング期間の長さが短いた 
め, ビデオ信号の 1 ラインには 12 サンプル，すなわ ち，4チャンネルの音声信号の多重化を行う場合に は, チャンネル当たり 3 サンプルの音声信号データし か多重化できない。この値は，1ライン当たりの実際 の音声信号サンプル数よりも小さく，したがって，通 常の映像ラインで伝送できなかった音声信号サンプル を垂直ブランキング期間にまとめて伝送する必要があ る.垂直ブランキング期間にまとめて伝送する音声信 号のサンプル数は, コンポジットNTSCの場合で音 声信号 1 チャンネル当たり約 46 サンプル, コンポジ ットPALの場合で同約 51 サンプルになる。このた めに, 本チップセットのエンコーダLSI およびデコ ーダLSIには, 各々 28 ビット $\times 256$ ワードのバッフ アRAM を内蔵しており，音声 1 チャンネルあたり 64 サンプルの音声信号データの時間軸補正が可能で ある。

本チップセットでは, このバッファ RAM 20 ビ ット音声と $\mathrm{C}, \mathrm{U}, \mathrm{V}, \mathrm{Z}$ の各フラグからなる 24 ビッ 卜幅の音声パケット用バッファ RAM と, オキジャ リに相当する 4 ビット幅の拡張パケット用のバッファ RAMに分割し, 音声信号の伝送に対応している. 特 にエンコーダLSIに扔いては, 拡張パケットの多重 化時にビデオクロックでの高速読出しが必要になるの で, 3 ポートRAMを使用し 2 つのポートで交互に 読出しを行っている.

また，ビデオ信号と音声信号の同期をとるために， 音声フレーム周期毎にバッファ RAM のリードアド レスとライトアドレスを比較し，このアドレス差が所 定の值となるようリードアドレスを制御している。さ らに, このアドレス差の設定値を外部より指定するこ とにより, 音声信号の遅延時間を可変可能としてい る.

シリアルディジタルビデオインタフェースでは, 音 声 4 チャンネル毎に 1 つのグループを構成する。コン ポジットビデオ信号では, 水平ブランキング期間が短 く音声信号は 1 グループ ( 4 チャンネル)しか多重化で きないが，コンポーネントビデオ信号では水平ブラン キング期間のデー夕容量が大きいため, さらに多くの 音声信号を伝送可能である。これに対応するため, 本 チップセットではエンコーダLSI およびデコーダ LSI の複数個使用によって, 最大 4 グループ(計 16 チ ヤンネル）を多重化できる。すなわち, 送信側では複 数のエンコーダLSI を縦列接続し, 最初のエンコー ダLSIによって, 第一のグループの音声信号を多重 化し, 以降のエンコーダ LSI では, 直前のエンコー ダLSIによって多重化された音声パケットのすぐあ

$1356(90)$

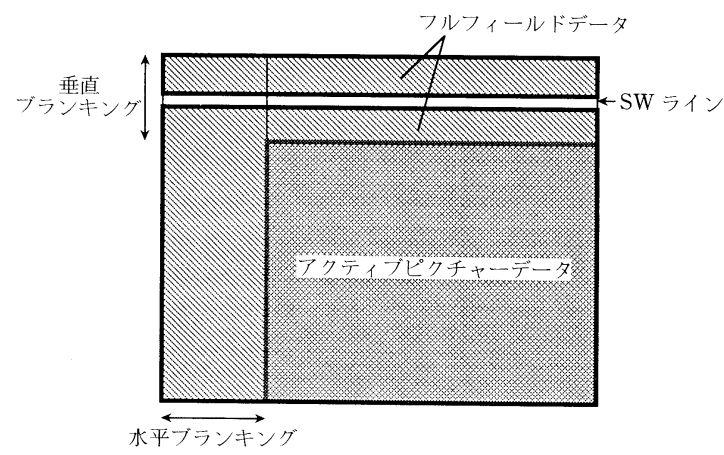

図 8 EDH 計算範囲

Location of samples included in EDH calculation.

とに次のグループの音声パケットを付け加える形で多 重化が可能である.

また, 各々の音声信号のグループに対し, グループ 内各チャンネルの有効/無効フラグ, サンプリング周 波数, 音声フレーム, ビデオ信号のディレイ量等を示 す音声制御データの多重化にも対応した。

\section{$3.3 \mathrm{EDH}$}

シリアルディジタルビデオインタフェースでは, 伝 送エラーの監視のために, 図 8 に示すように, 1 フィ ールド間の補助デー夕を含めた全データの CRCC お よび, 1 フィールド間のアクティブビデオ領域のみの データのCRCC を送信側にて計算し $\mathrm{EDH}$ パケット として伝送する。 CRCC の生成多項式は

$$
C(X)=X^{16}+X^{12}+X^{5}+1
$$

である. 本チップセットでは, エンコーダLSI およ びデコーダ LSI に並列処理 CRCC 計算回路を各々 2 回路内蔵し, 伝送エラーの監視に対応した。

\section{4 並列処理スクランブラ}

通常, チャンネルコーディングのためのスクランブ ル・デスクランブルは, パラレルデータをシリアルに 変換した後に行われる.しかしこの場合, スクランブ ル・デスクランブル回路を, 回路増加に対する消費電 力増加の大きいバイポーラ IC 側に設けなければなら ないため, チップセット全体としての消費電力が増大 してしまう。そこで, 本チップセットでは, 並列処理 によるスクランブル・デスクランブル回路および, 受 信側でのワード同期回路をCMOS LSI 側に内蔵した。 したがって，アナログ回路と最小限のロジック回路の みをバイポーラ IC 側で受け持つことになり, チップ セット全体としての消費電力を低減できた。

\section{4. むす び}

スタジオ規格ディジタルビデオ信号のシリアル伝送 


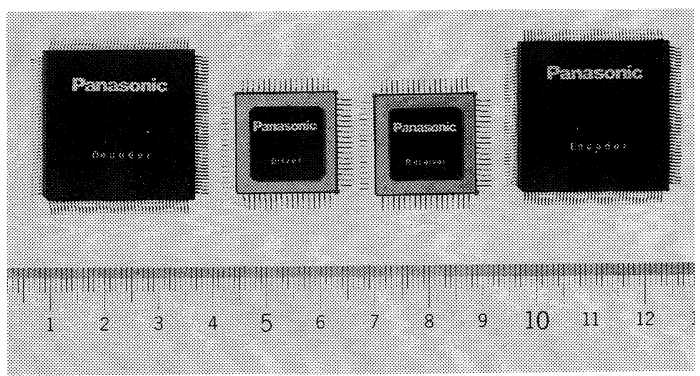

写真 2 シリアルディジタルビデオインタフェースチ ップセット

Chip set for serial digital video interface.

に要求される機能をまとめた 4 チップからなるシリア ルインタフェース用チップセットを開発した．写真 2 にチップ写真を示す. アナログ FIR フィルタを用い た自動波形等化回路採用の結果, 同軸ケーブルでの長 距離伝送が可能となった。 また, 本チップセットによ りディジタルビデオ信号のシリアル伝送を低コストか つ小スペースにて実現でき, ディジタル AV 機器へ のシリアルインタフェースの組み込みが容易になっ た。

最後に, 本開発を進めるにあたりご指導ご協力をい ただいた松下電器産業(株) AV 研究所, 映像技術研究 所, ならびに映像研究所の開係各位に深く感謝致しま す.

\section{〔参 考 文 献〕}

1) SMPTE 259M, "Proposed SMPTE Standard-10 Bit 4 :
2: 2 Component and 4 fsc NTSC Composite Digital Signals-Serial Digital Interface"

2）久保，上田：“10 B スクランブル方式”, テレビ誌， 46，4, pp. 409-413 (Apr. 1992)

3) Proposed SMPTE S17.100, "Proposed SMPTE Standard -Formatting AES/EBU Audio and Auxiliary Data into Serial Digital Video Ancillary Data Space"

4) SMPTE RP165, "Proposed SMPTE Recommended Practice-Error Detection Checkwords and Status Flags for Use in Bit-serial Digital Interface for Television"

5) SMPTE 125M, "Bit Parallele Digital Interface-Component Video Signal 4:2:2"

6）志村：“海底同軸ケーブル通信方式”, pp. 85-86, 電子通信 学会 (1978)

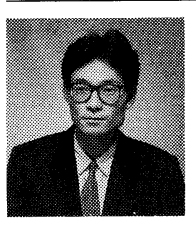

势标 架ざひ彦 昭和 59 年, 京都大学工学部 電子工学科卒業. 平成 3 年, 松下電器産業 (株)に入社. 以来, ディジタルビデオ信号の 伝送技術開発に従事. 現在, 同社映像研究所 に所属. 正会員.

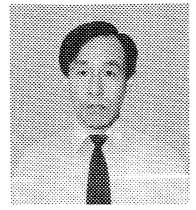

妹尾势憲 昭和 48 年, 大阪大学工学部 通信工学科卒業. 昭和 50 年, 同大学院修士 課程修了. 同年, 松下電器産業(株) に入社. ディジタルオーディオ機器等の開発に従事. 昭和 63 年〜平成 2 年, 米国マサチューセッ ツ工科大学客員研究員. 以来, 画像の符号化 伝送方式および機器の開発に従事. 正会員.

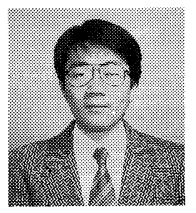

神野 一平 昭和 59 年, 名古屋大学工学 部電気工学科卒業. 昭和 61 年, 同大学院修 士課程修了. 同年, 松下電器産業(株) に入 社. 現在, 同社映像研究所にて, アナログお よびディジタル信号の受信, 変復調, 伝送関 係の研究開発に従事. 